\title{
ANEMIA WITH FEBRILE SEIZURE IN CHILDREN AGED FROM SIX MONTHS OLD TO FIVE YEARS OLD AT GOTONG ROYONG HOSPITAL SURABAYA
}

Calvindoroputro $^{1)}$, Susan $^{2)}$, Pauline Meryana ${ }^{3)}$

\begin{abstract}
Introduction: Febrile seizure is one type of seizure that commonly occurs in groups of children less than five years of age, especially at the age of 2 years. The incidence of febrile seizures in children is often very worrying for parents.

Aim: The purpose of the study was to examine the relationship of anemia with the occurrence of febrile seizures in children aged six months - five years old at Gotong Royong Hospital Surabaya.

Methods: This study uses an Observational Study carried out with a case-control design and purposive sampling method. The study was conducted in one bone that took place between July 25 and August 25, 2017. The study was conducted by taking secondary data from medical records of children aged six months - five years who were hospitalized, consisting of 21 children with febrile seizure and 21 children with fever without a seizure, and $\mathrm{Hb}$ recorded in hospitalized patients. Analyze with the chi-square test.
\end{abstract}

Results: Children with anemia, 8.5 times more likely to experience febrile seizures than children who did not experience anemia.

Conclusion: The results showed a significant relationship between anemia and febrile seizure $(p=0.002)$ with an odds ratio of 8.5. Therefore, children with anemia have a higher risk of having a febrile seizure.

Keywords: Anemia, Febrile seizure

\footnotetext{
${ }^{1)}$ Student of Faculty of Medicine Widya Mandala Catholic University Surabaya, Kalisari Selatan 1 Surabaya Email : calvindoroputro@gmail.com

${ }^{2)}$ Pediatric Department Faculty of Medicine Widya Mandala Catholic University Surabaya, Kalisari Selatan 1 Surabaya

${ }^{3)}$ Neurology Department Faculty of Medicine Widya Mandala Catholic University Surabaya, Kalisari Selatan 1 Surabaya
} 


\section{INTRODUCTION}

According to the Consensus for the Management of Fever Seizures (Kejang Demam or KD), the Indonesian Pediatrician Association (Ikatan Dokter Anak Indonesia or IDAI), KD is a seizure that occurs at an increase in body temperature (rectal temperature above $38^{\circ} \mathrm{C}$ ) caused by an extracranium process ${ }^{1}$. $\mathrm{KD}$ is a type of seizure that is common in $2-5 \%$ of children aged less than five years old, especially at the age of two years old. The most common age of $\mathrm{KD}$ in children is six months to 22 months $^{3}$. Simple KD is a seizure that lasts less than 15 minutes, does not recur in 24 hours and is the most common form of childhood seizures that occur in $2-5 \%$ of children in the United States $^{4}$. In Europe and the United States, 2$5 \%$ of children (more common in boys) experience at least one $\mathrm{KD}$ before the age of five years. Although preliminary studies in India found up to $10 \%$ of children experiencing $\mathrm{KD}$, recent data shows that incidence in India is similar to that in the West $^{5}$. Research in Japan found higher rates, namely: Tsuboi (1986) scored around 7\% and Maeda (1993) got 9.7\% (in men $10.5 \%$ and in women $8.9 \%)^{6,7}$.

Risk factors for KD are age, sex, fever temperature, family history of previous $\mathrm{KD}$ members, complications in labor (preterm and Low Birth Weight or
LBW), recurrent infections, and iron status $(\text { anemia })^{2}$.

Incidence of $\mathrm{KD}$ in children is often very worrying for parents. According to the study of Wals and Shirasaka (1994), severe anxiety experienced by mothers in children who have KD is caused by mothers worried about brain damage in children, children become injured, unable to breathe, become unconscious, and even $\mathrm{die}^{8}$. In the Westerlain and Shirasaka (1994) study it was found that seizure seizures can damage the brain ${ }^{9}$, whereas according to the study of Aicardi and Chevrie (1979), it was reported that of 402 children with KD, 131 found one or more sequels, 114 had epilepsy, 54 had mental retardation, 37 suffered from other neurological disorders including 24 with hemiplegia. Children who suffer from this sequel, before $\mathrm{KD}$ are normal and also found that the occurrence of sequels is greater if $\mathrm{KD}$ lasts longer than 30 minutes or is unilateral compared to short and bilateral ones ${ }^{10}$.

The results of Van Stuijven Berg's research (1999) shows that $17 \%$ of parents of children with KD have no knowledge of seizures and $47-77 \%$ consider their children to be seriously ill and will end in death. The Parmar study (2001) in India found $77.9 \%$ of parents of KD patients had no knowledge of $\mathrm{KD}$ and $90 \%$ thought their child would die, while $52 \%$ of 
parents said that they checked their child's temperature every $\leq 1$ hour when their child had a fever , 25\% give antipyretics for temperatures $<37.8^{\circ} \mathrm{C}\left(<100^{\circ} \mathrm{F}\right)$, and $85 \%$ will wake their children to give antipyretics. Unfortunately, most parents give the wrong antipyretic dose, $15 \%$ of parents give an excessive dose of acetaminophen or ibuprofen. Parents' excessive worry is the main cause of the incident $^{11,12}$.

According to the study of Pellock (2013), it was found that anemia is one of the risk factors for $\mathrm{KD}^{2}$. Anemia is a condition where a person experiences a shortage of red blood cell volume and low concentration of hemoglobin $(\mathrm{Hb})$ in the blood $^{13}$. Anemia can also be interpreted as a state of red blood cells that can not carry enough oxygen (O2) into the body's tissues $^{14}$, so that anemia causes reduced ability to transport $\mathrm{O} 2$ into the tissue. Lack of $\mathrm{O} 2$ in tissues can cause hypoxia where $\mathrm{O} 2$ is needed in the active transport process of $\mathrm{Na}^{+}-\mathrm{K}^{+}$ions which is useful to stabilize the condition of nerve cell membranes, disruption of nerve cell membrane stability can result in intracellular $\mathrm{Na}^{+}$ion concentrations increasing, triggering depolarization, if this condition is at a level which can still lead to KD during fever ${ }^{15}$.

According to the World Health Organization (WHO) in the Worldwide
Prevalence of Anemia, the total world population suffering from anemia is 1.62 billion people with a prevalence in preschool children $47.4 \%$ (767 million), while in primary school children 25.4\% (411 million) and 305 million school children worldwide suffer from anemia ${ }^{13}$. Nearly $50 \%$ of children in developing countries experience anemia. In Indonesia, the incidence of anemia in children is still often found. Globally, the prevalence of anemia in school-age children shows a high rate, which is $37 \%$, while in Thailand it is $13.4 \%$ and in India $85.5 \%$. The prevalence of anemia among children in Asia reaches $58.4 \%$. This figure is higher than the average in Africa, where the prevalence of anemia in Africa is only $49.8 \%{ }^{16}$.

There is some debate about the role of anemia in KD. Research that supports that there is a significant relationship between anemia and KD, namely Malla research (2015), Dasmayanti (2015), Sharawat (2016), Srinivasa (2014), Khanis (2010), and Hartfield (2009) report that anemia is one of risk factors that can reduce the threshold of seizures during fever which facilitates $\mathrm{KD}^{17-22}$, whereas according to the study of Bidabadi (2009), Amirsalari (2010), Omran (2009), and Sherjil (2010) it was reported that anemia did not have a significant relationship as a risk factor for $\mathrm{KD}^{23-25}$. The research results 
above, will be explained further in the discussion chapter.

Pisacane research (1996) reports that anemia is a risk factor for $\mathrm{KD}$ generation in children under 2 years old ${ }^{26}$. Mittal's research (2002) reported that iron deficiency in experimental animals showed a significant decrease in the levels of aminobutyric acid gamma (GABA) in the brain. Agarwal's (2002) study reported that iron deficiency showed a significant increase in glutamic acid levels in the brain. An imbalance between the neurotransmitter glutamic acid facilitator and GABA inhibitors plays a role in the onset of seizures ${ }^{27}$.

Because anemia can be a risk factor for $\mathrm{KD}$ in children, researchers are interested in examining the relationship of anemia to the occurrence of $\mathrm{KD}$ in children aged 6 months old - 5 years old. Thus, it is hoped that the incidence of KD can be prevented by improving the condition of anemia in children.

Based on the data that has been obtained and the results of several related studies, we investigate the relationship of anemia with the occurrence of $\mathrm{KD}$ in children aged 6 months old - 5 years old.

\section{METHODS}

This study uses a retrospective observational analytic research method with a case control research design. The calculation of sample size takes into account the longest group or not, and whether there exist a control group.

The number of samples in this study were 42 samples, consisting of 21 groups of $\mathrm{KD}$ and 21 groups of fever without seizures from 1 January 2016 to 31 July 2017. The inclusion criteria for this study were KD pediatric patients and fever without seizures for men and women aged 6 months old - 5 years old with a temperature of $\geq 38^{\circ} \mathrm{C}$ measured when first arrived, and have a good nutritional status of the hospitalized, as well as $\mathrm{Hb}$ inpatient data at the first examination recorded in the medical record.

The exclusion criteria for this study were patients who had previous neurological abnormalities, seizures caused by intracranial infections, seizures due to other causes, patients who had a history of previous epilepsy, KD pediatric patients and fever without seizures with temperatures $<38 \mathrm{oC}$, examination of hemoglobin levels from the clinic or home other illnesses, and KD child patients who have a history of KD before. We also used the purposive sampling technique in this study.

The research was begun by determining the study population; namely, all children aged 6 months - 5 years with fever who were treated at the Gotong Royong Hospital Surabaya in the period 
January 2016 to July 2017. From this population, samples were taken using a purposive sampling technique, where all members populations that meet the inclusion and exclusion criteria. Data collection is taken from medical record data. Data taken from medical records are gender, age, cause of fever, temperature, and hemoglobin level at the first examination at Gotong Royong Hospital, Surabaya. The examination of blood samples is done by taking three ccs of blood (vein mediana cubiti). Blood samples are inserted into the EDTA tube then homogenised. Then, the EDTA tube is opened when the blood is homogenous. The blood sample is calculated using a tool automatic hematology analyzer, the Sysmex KX-21 brand, which has the same standard values with WHO. Data compilation and tabulation is done after all data has been collected to facilitate data analysis. Data regarding anemia and KD were analyzed using the help of the SPSS program version 23.0. The results of data analysis are presented in tabular and narrative form. All results of data collection and analysis are discussed, and conclusions are drawn from the study, and suggestions are given for further research.

\section{RESULT}

The results of the distribution of the research sample on the medical record data of children aged 6 months old - 5 years old who were hospitalized in Surabaya Gotong Royong Hospital in JulyAugust 2017, we found children with KD (add up to 100\%) and also children with fever without seizures (add up to 100\%).

Table 1 Sample Distribution Based on Gender

\begin{tabular}{ccc}
\hline Sex & $\begin{array}{c}\text { Children w/ } \\
\text { KD }\end{array}$ & $\begin{array}{c}\text { Children w/ } \\
\text { fever without } \\
\text { seizures }\end{array}$ \\
\hline Male & $9(42,86 \%)$ & $11(52,38 \%)$ \\
\hline Female & $12(57,14 \%)$ & $10(47,62 \%)$ \\
\hline
\end{tabular}

Based on Table 1, boys with KD were nine samples (42.86\%), and girls with KD were 12 samples (57.14\%). We also gathered data on boys with fever without seizures for 11 samples (52.38\%) and girls with fever without seizures for ten samples $(47.62 \%)$.

Table 2 Sample Distribution Based on Age

\begin{tabular}{lccc}
\hline Age & $\begin{array}{c}\text { Children w/ } \\
\text { KD }\end{array}$ & $\begin{array}{c}\text { Children w/ } \\
\text { fever without } \\
\text { seizures }\end{array}$ & Total \\
\hline $6-12 \mathrm{~m} / \mathrm{o}$ & $9(42,86 \%)$ & $3(14,29 \%)$ & 12 \\
\hline $1-2 \mathrm{y} / \mathrm{o}$ & $9(42,86 \%)$ & $3(14,29 \%)$ & 12 \\
\hline $2-3 \mathrm{y} / \mathrm{o}$ & - & $4(19,05 \%)$ & 8 \\
\hline $3-4 \mathrm{y} / \mathrm{o}$ & - & $4(19,05 \%)$ & 4 \\
\hline $4-5 \mathrm{y} / \mathrm{o}$ & $1(4,76 \%)$ & $4(19,05 \%)$ & 5 \\
\hline
\end{tabular}

Based on Table 2, most children experience $\mathrm{KD}$ in the age range between 6 months old to 12 months old, as many as nine patients $(42.86 \%)$ and the age range of 1 year old to 2 years old, as many as nine patients $(42.86 \%)$.

Table 3 Sample Distribution Based on Temperature

\begin{tabular}{ccc}
\hline $\begin{array}{c}\text { Body } \\
\text { Temperature } \\
\left({ }^{\circ} \mathrm{C}\right)\end{array}$ & Children w/KD & $\begin{array}{c}\text { Children w/ } \\
\text { fever without } \\
\text { seizures }\end{array}$ \\
\hline $38,1-38,5$ & $7(33,33 \%)$ & $9(42,86 \%)$ \\
\hline
\end{tabular}




\begin{tabular}{ccc}
\hline $38,5-39,0$ & $6(28,57 \%)$ & $7(33,33 \%)$ \\
\hline $39,1-39,5$ & $7(33,33 \%)$ & $5(23,81 \%)$ \\
\hline $39,6-40,0$ & $1(4,78 \%)$ & - \\
\hline Total & $21(100 \%)$ & $21(100 \%)$ \\
\hline
\end{tabular}

Based on Table 3, as many as seven patients experienced the most KD, namely at temperatures of $38^{\circ} \mathrm{C}$ to $38.5^{\circ} \mathrm{C}$, with a percentage of $33.33 \%$ and with the same number of patients at temperatures of $39.1^{\circ} \mathrm{C}$ to $39.5^{\circ} \mathrm{C}$, with a percentage of $33.33 \%$.

Table 4 Percentage of Fever Causes in KD Children Aged 6 Months Old - 5 Years Old at Gotong Royong Hospital Surabaya

\begin{tabular}{l|l}
\hline & Fever Causes in KD \\
\hline Acute & $19(90,48 \%)$ \\
\hline Bronchiolitis & $1(4,76 \%)$ \\
\hline Bronchitis & $1(4,76 \%)$ \\
\hline
\end{tabular}

Based on Table 4, the percentage of causes of fever in KD children aged 6 months old - 5 years old at Gotong Royong Hospital Surabaya, we get 90.48\% in acute pharyngitis, $4.76 \%$ in bronchiolitis, and $4.76 \%$ in bronchitis.

Table 5 Percentage of Causes of Fever Without Seizures Children 6 Months Old - 5 Years Old at Gotong Royong Hospital Surabaya

\begin{tabular}{l|c}
\hline & $\begin{array}{l}\text { Fever Causes } \\
\text { (without seizures) }\end{array}$ \\
\hline Acute Pharyngitis & $4(19,04 \%)$ \\
\hline Dengue Fever & $4(19,04 \%)$ \\
\hline Dengue Hemorrhagic & $4(19,04 \%)$ \\
Fever & $4(19,04 \%)$ \\
\hline Acute Diarrhea with & $3(14,28 \%)$ \\
\hline Myphoid Fever & \\
\hline
\end{tabular}

\begin{tabular}{l|c}
\hline Salmonella Typosa & $1(4,76 \%)$ \\
\hline Bronchitis & $1(4,76 \%)$ \\
\hline
\end{tabular}

Based on Table 5, the percentage of causes of fever in febrile seizures in children was $19.04 \%$ in Acute Pharyngitis, 19.04 in dengue fever, $19.04 \%$ in dengue hemorrhagic fever, $19.04 \%$ in acute diarrhea, moderate dehydration, 14, 28\% in Typhoid Fever, $4.76 \%$ in bronchitis and $4.76 \%$ in Salmonella Typosa.

Tabel 6 Distribusi Sampel Berdasarkan Kadar $\mathrm{Hb}$

\begin{tabular}{lll}
\hline & $\begin{array}{l}\text { Children } \\
\text { KD }\end{array}$ & $\begin{array}{l}\text { Children w/ fever } \\
\text { without seizures }\end{array}$ \\
\hline Mean & $10,85 \mathrm{~g} / \mathrm{dL}$ & $11,70 \mathrm{~g} / \mathrm{dL}$ \\
\hline Minimum & $9,2 \mathrm{~g} / \mathrm{dL}$ & $9,3 \mathrm{~g} / \mathrm{dL}$ \\
\hline Maximum & $12,9 \mathrm{~g} / \mathrm{dL}$ & $13,6 \mathrm{~g} / \mathrm{dL}$ \\
\hline
\end{tabular}
Based on Table 6, the children with $\mathrm{KD}$ group of $\mathrm{Hb}$ levels during the first laboratory examination at Gotong Royong Hospital had the lowest value of $9.2 \mathrm{~g} / \mathrm{dL}$, the highest of $12.9 \mathrm{~g} / \mathrm{dL}$, and an average of 10.85 $\mathrm{g} / \mathrm{dL}$. In the fever without seizure group, the $\mathrm{Hb}$ number at the first laboratory examination at the Gotong Royong Hospital had the lowest value of $9.3 \mathrm{~g} / \mathrm{dL}$, the highest of $13.6 \mathrm{~g} / \mathrm{dL}$, and an average of $11.70 \mathrm{~g} / \mathrm{dL}$.

Tabel 7 Cross tabulation between anemia and KD

\begin{tabular}{|c|c|c|c|c|}
\hline $\begin{array}{l}\mathrm{Hb} \\
\text { Value }\end{array}$ & KD & $\begin{array}{l}\text { Fever } \\
\text { without } \\
\text { seizures }\end{array}$ & $\begin{array}{l}\text { Odds } \\
\text { Ratio }\end{array}$ & Significance \\
\hline $\mathrm{Hb}$ & 14 & 4 & 8,5 & $\mathrm{p}=0,002$ \\
\hline$<11$ & $(77,8 \%)$ & $(22,2 \%)$ & & \\
\hline $\mathrm{Hb}$ & 7 & 17 & & \\
\hline$\geq 11$ & $(29,2 \%)$ & $(70,8 \%)$ & & \\
\hline Total & $\begin{array}{c}21 \\
(50 \%)\end{array}$ & $\begin{array}{c}21 \\
(50 \%)\end{array}$ & & \\
\hline
\end{tabular}

Table 7, then analyzed using the chi- 
square test to find the relationship between variables. From the analysis, it was obtained a significance value of $0.002(p=$ 0.002) which means $\mathrm{p}<\alpha(\alpha=0.05)$ which means that $\mathrm{H}_{0}$ was rejected and $\mathrm{H}_{1}$ was accepted, so it can be concluded that in this study there was a significant relationship between Anemia and the occurrence of $\mathrm{KD}$ with an odds ratio of 8.5 .

\section{DISCUSSION}

This chapter explains the discussion of research results covering the demographic characteristics of KD patients and the results of the analysis of the relationship between anemia and the occurrence of $\mathrm{KD}$ in pediatric patients aged 6 months old - 5 years old at Gotong Royong Hospital, Surabaya. The study was conducted on 21 groups of children with KD and 21 groups children with fever without seizures" who were hospitalized from January 1, 2016, to July 31, 2017, at the Gotong Royong Hospital in Surabaya, which met the criteria for inclusion and exclusion of researchers. Samples were taken using a purposive sampling technique on July 25, 2017-August 25, 2017, with diagnostic data and hemoglobin levels from medical records.

In this study, most KD patients by gender were female, as many as 12 patients $(57.14 \%)$. In the age group, the incidence of KD in many children occurs at the age of 6 months old to 12 months old. That is because age is related to the brain development phase, namely the developmental windows, which are the brain development phase of the organization.

Based on the temperature, the highest temperature obtained by $\mathrm{KD}$ patients ranged from 38.1-38.5oC and $39.1-39.5^{\circ} \mathrm{C}$ as many as $14 \mathrm{KD}$ patients out of $21 \mathrm{KD}$ patients. Based on the cause of fever, the most common cause of $\mathrm{KD}$ patients and fever without seizures, namely in the form of acute pharyngitis by 90.48\% and 19.04\%. Based on Hb levels, the KD group had an average Hb level of $10.85 \mathrm{~g} / \mathrm{dL}$, while the group of fever without seizures had an average $\mathrm{Hb}$ level of $11.70 \mathrm{~g} / \mathrm{dL}$.

Based on the results of the chisquare test, we obtained the p-value of 0.002 ( $\mathrm{p}$-value $<0.05$ ). This means that there is a significant relationship of anemia with KD in children aged 6 months old to age 5 years old at Gotong Hospital Royong Surabaya. This finding is in line with Malla's study (2015), which reported that of 162 children aged 6 months old - 5 years old consisting of $92 \mathrm{KD}$ children and 70 children with fever without seizures, it was found that KD children had anemia of $61.95 \%$, while children with fever without 
Anemic seizures were $21.42 \%$ (17) and Dasmayanti (2015) also reported that 22 out of $25 \mathrm{KD}$ samples were anemic $(\mathrm{Hb}$ $<11 \mathrm{~g} / \mathrm{dL}$ ). In contrast, only 2 out of 25 fever samples without seizures had anemia. (18). The calculation of the odds ratio in this study was 8.5 , so it can be interpreted that children (aged 6 months old - 5 years old) with anemia have an 8.5 times risk of developing $\mathrm{KD}$ compared with children who do not have anemia. This finding is in line with research conducted by Khanis (2010) who reported that children with anemia had a risk of developing KD 10.8 times greater than children without anemia (21), Hartfield's study (2009) also reported that children with anemia had two times greater risk for developing KD seizures (22), and Putri's research (2017) reported that $45.2 \%$ of the $42 \mathrm{KD}$ groups had more anemia than the fever without seizure group, that only had $19 \%$. Children with anemia had a risk of 3.5 times more likely to experience $\mathrm{KD}$ compared to children who do not have anemia $^{28}$.

\section{CONCLUSION}

Based on the results of research conducted on the relationship of anemia with the occurrence of $\mathrm{KD}$ in children aged 6 months old - 5 years old at Gotong Royong Hospital Surabaya against 42 samples, consisting of 21 groups of $\mathrm{KD}$ and 21 groups of fever without seizures from 1 January 2016 to 31 July 2017 , it was concluded that there was a significant relationship between anemia and the occurrence of $\mathrm{KD}$ in children aged 6 months old - 5 years old. From the data obtained in this study, it can be concluded that anemia in children $(\mathrm{Hb}$ level $<11 \mathrm{~g} /$ $\mathrm{dL}$ ) is one of the significant indicators and needs more attention as a risk factor for KD.

\section{REFERENCES}

1. Pusponegoro HD, Widodo DP, Ismael S. (2006). Konsensus Penatalaksanaan Kejang Demam (2nd ed.). Jakarta: Badan Penerbit IDAI; hal 1-9.

2. John M. Pellock, S. S. (2013). Recent Research on Febrile Seizures: A Review. Journal of Neurology \& Neurophysiology, 04(04). doi:10.4172/2155-9562.1000165.

3. Farwell JR, Blacner G, Sulzbacker S. First febrile seizures characteristics of the child, the seizures and the illness. Clin Pediatr 1994;33:263-7.

4. Srinivasan J, Wallace KA, and Scheffer IE. Febrile Seizures. Australian Family Physician. 2005;34(12):1021-1025.

5. Shinnar $S$ and Glauser TA. Febrile Seizures. Journal of Child Neurology. 2002;17(Supp11):S44-S52.

6. Tsuboi T. seizures of childhood. Acta Neurol Scand 1986;110 (suppl):74.

7. Maeda H, Kumagi K, Maekawa K. Epidemiologic study of febrile convulsions based on elementary schools Brain \& Dev 1993;15:392.

8. Wals, A.M., Edwards, H.E., \& Fraser, H. (2008). Attitudes and subjective 
norms: determinants of parents' intentions to reduce childhood fever with medications.. Health Education Resecearch, 24 (3),531- 545.

9. Wasterlain CG, Shirasaka Y. Seizures, brain damage and brain development. Brain \& Dev 1994; 16:279-95.

10. Aiccardi J, Chevrie JJ. Febrile convulsions. Neurological sequelae and mental retardation. In Brazier MAB, Coceani G (eds) Brain dysfunction in infantile febrile convulsions Raven Press, New York 1979;247-57.

11. Millichap, J. G. (2008). Clinical Features of Prolonged Febrile Seizures. Pediatric Neurology Briefs, 22(7)56. doi: 10.15844/pedneurbriefs22-7-10.

12. Crocetti, M., Moghbeli, N., \& Serwint, J. (2001). Fever Phobia Revisited: Have Parenteral Misconceptions About Fever Changed in 20 Years ? PEDIATRICS, 107 (6), 1241-1246. doi: 10.1542/peds.107.6.1241.

13. WHO. Worldwide prevalence of anemia 1993 - 2005, WHO global database on anaemia. Geneva: WHO library cataloguing-in-publication data; 2008.

14. McLean, E., Cogswell, M., Egli, I., Wojdyla, D., \& De Benoist, B. (2008). Worldwide prevalence of anaemia WHO Vitamin and Mineral Nutrition Information System, 1993-2005. Public Health Nutrition, 12(04), 444. doi: $10.1017 / \mathrm{s} 1368980008002401$.

15. Wu J, Fisher RS. Hyperthermic spreading depressions in the immature rat hippocampal slice. J Neurophysiol 2000;84:1355-60.

16. Arisman. Gizi dalam daur kehidupan. Jakarta: Penerbit Buku Kedokteran EGC; 2010. 121-128.
17. Malla, T., Sathian, B., Chettri, P., Singh, S., \& Ghimire, A. (2015). Simple Febrile Convulsion and Iron Deficiency Anemia A Co-relation in Nepalese Children. American Journal of Public Health Research, 2015, No. 5A, 11-16, 3, 11-16. Available from http://pubs.sciepub.com/ajphr/3/5A/4.

18. Dasmayanti, Y., Anidar, A., Imran, I., Bakhtiar, B., \& Rinanda, T. (2016). Hubungan Kadar Hemoglobin dengan Kejang Demam Pada Anak Usia Balita. Sari Pediatri, 16(5), 351. doi:10.14238/sp16.5.2015.351-5.

19. Sharawat, I. K. (2016). Evaluation of Risk Factors Associated with First Episode Febrile Seizure. JOURNAL OF CLINICAL AND DIAGNOSTIC RESEARCH. doi:10.7860/jcdr/2016/18635.7853.

20. Srinivasa, S., \& Reddy, S. P. (2014). Iron defeiciency anemia in children with simple febrile seizures-A cohort study. Current Pediatrics.

21. Khanis A. Defisiensi besi sebagai parameter $S T f R$ sebagai faktor risiko bangkitan kejang demam. Semarang: Departemen Ilmu Kesehatan Anak Universitas Diponegoro, 2010.

22. Hartfield DS, Tan J, Yager JY, Rosychuk RJ, Spady D, Haines C et al. The association between iron deficiency and febrile seizures in childhood. Clin Pediatr (Phila). 2009 May;48(4):420-6.

23. Bidabadi, E., \& Mashouf, M. (2009). Association between iron deficiency anemia and first febrile convulsion: A case-control study. Seizure, 18(5), 347-351.

doi:10.1016/j.seizure.2009.01.008.

24. Amirsalari S, Keihani doust ZT, Ahmadi M, Sabouri A, Kavemanesh Z, Afsharpeyman $\mathrm{SH}$ et al. Relationship 
between iron deficiency anemia and febrile seizures. Iran J Child Neurol. 2010;4(1):27-30.

25. Salehi Omran MR, Tamaddoni A, Nasehi MM, Babazadeh H, Alizadeh navaei R. Iron status in febrile seizure: a case-control study. Iran $\mathrm{J}$ Child Neurol. 2009;3(3):39-42.

26. Pisacane A, Sansone R, Impagliazzo N, Cappolo A, Rolando P, Tregrossi C, dkk. Iron deficiency anemia and febrile convulsion. BMJ 1996;12:313-43.

27. Mittal RD, Pandey A, Agarwal KN. Effect of latent iron deficiency on GABA and glutamate neuroreceptors in rat brain. Indian $\mathrm{J}$ Clin Biochem 2002; 17 (2) : 1-6.

28. Putri, L. M.(2017). Hubungan Anemia Defisiensi Besi dengan Kejang Demam pada Anak Balita, 5, 68-77. Available from:

https://www.researchgate.net/publicati on/309876667_Hubungan_Kadar_He moglobin_dengan_Kejang_Demam_Pa da_Anak_Usia_Balita/download 